\title{
The Once and Future Great Lakes Country: An Ecological History
}

By John L. Riley. 2013. McGill-Queen's University Press, 1010 Sherbrooke West, Suite 1720, Montreal, QC, Canada, H3A 2R7. 516 pages, 39.95 CAD, Cloth.

Wow. Check out this book if you are craving a read with vast dimensions. I don't mean the physical book, either. That, in hardcover, has a comfortably satisfying heft like your favourite dictionary or rock purloined from nature. The cover alone is breathtaking, an oblique aerial view of a landscape in orange and gorgeous water blue. The book doesn't identify the place, and I couldn't either. Even if it is cover art, to provide an aerial photo with no label is the perfect way to torture a geographer, or at least to cause one to spend a lot of time scanning around on Google Earth. Instead I enlisted friends to the case via Facebook. We think, thanks to Sean Blaney and Becky Whittam, that it's Matchedash Bay looking north to Georgian Bay.

I will declare my bias. I know many reading this join me in calling the Great Lakes country home, our lives framed by these lakes. The Bruce Peninsula and Lake Huron shoreline, for instance, have scoured our childhood memories. The Waterloo region was the landscape and ecology lab through university. Then we were in thrall to the thrum of bird migration over the Lake Erie shore. Ian Tamblyn's Woodsmoke and Oranges embodies our time with Lake Superior. John Riley's work is rich in time, drilling into prehistory and telescoping into the future. We can place it on the same library shelf as other ecological and environmental histories, both regional and broader in scope, but if offers quite a bit of cultural introspection too, an element you might not always find elsewhere.

At the time of publication, Riley was a senior science advisor for the Nature Conservancy of Canada. He begins this story on his own land where with his family he occupies an old farm (there are thousands like it, he says) in the Great Lakes basin. From there he builds outward in both time and geography to follow this remarkable region through so many passages. It is very well-written. It pulled me along, with loads of fascinating information, analysis and evocation of landscapes, wildlife, people and peoples. Human beings are the significant force of ecological change for much of the book's span, so their history and influence are sensitively portrayed. Riley skillfully stitches past with present and future so that the reader never forgets the relevance of any one to the other. The book also is thoroughly referenced and noted, with much reliance on first person accounts and other authors.

Just to whet your curiosity, I offer these chapter titles: "Land Beyond Memory: Before 1500"; "Wilding the Land with War: the 1700s"; "Taming the Unforested: Prairies, Alvars, Barrens, Cliffs, Bogs and Fens" and "Restoration: A New Native Landscape". I am a fool for prehistory and early history, so those chapters held me more tightly than the later ones. The final chapters contain large amounts of optimism, making the case that the current trend is actually toward conservation rather than the opposite. The optimism puzzles me, but I will take it because I so thirstily want it.

I can recommend this book without reservation. You may or may not take issue with the author's points of view on some subjects, or interpretation of historical records (there is a heck of a lot to consider!) but it is finely presented for your inspection. As well, Riley's writing voice is utterly human and companionable. The hardcover edition is lovely to have. I bought the e-book as well, for ease of searching by word.

BEv McBRIDE

574 Tweedsmuir Ave., Ottawa, ON, Canada, K1Z 5P2 